\title{
Analysis of the Word-Initial Segment with Reference to Lemmatising Zulu Nasal Nouns
}

\author{
M.H. Mpungose, Zulu Dictionary Project, \\ University of Zululand, Durban-Umlazi Campus, Isipingo, South Africa
}

\begin{abstract}
The process of lemmatising nasal nouns in the Zulu lexicon is problematic. The traditional method is to lemmatise a Zulu lexical noun by etymological noun-stem. This practice creates difficulties in harmonising lexical nouns with their syntactic application. Most authors and dictionary-makers are inconsistent in identifying the word-initial segment which determines the letter of the alphabet under which the lexical noun should be included. Consequently, dictionary users do not find Zulu dictionaries user-friendly. This article therefore proposes the principle of "a noun without initial vowel" as a method for lemmatising Zulu nasal nouns. It concludes that it is not necessary to delve into the derivational history of a lexical noun, but rather to focus on the product of the operation of morphophonological rules. The article also suggests the need to identify the distinctiveness of the segments of a syllable and to acknowledge that identical forms of a segment do occur at different segmental positions (initial, medial and final). Finally it is argued that the Zulu nasal noun class prefix is constructed according to an open syllable pattern defined by a general $\mathrm{CV}$-formula based on a VCV noun prefix open syllable pattern.
\end{abstract}

Keywords: ADJOINED LETTER, COMPOUND, COMPOSITE, CONSONANT, ELEMENT, ETYMOLOGICAL, EVOLUTIONARY, HOMORGANIC, INITIAL, INTRAVOWEL, LEMMA, LEMMATISE, LEXICAL, MORPHOPHONOLOGICAL, NASAL, NOUN CLASS PREFIX, SEGMENT, SYLLABLE, VOWEL

\section{Opsomming: Ontleding van die woordinisiële segment met verwysing na} die lemmatisering van nasale naamwoorde in Zoeloe. Die proses van lemmatisering van nasale naamwoorde in die Zoeloeleksikon is problematies. Die tradisionele metode is om leksikale selfstandige naamwoorde in Zoeloe volgens die etimologiese naamwoordstam te lemmatiseer. Hierdie gebruik veroorsaak moeilikhede by die harmonisering van leksikale selfstandige naamwoorde met hul sintaktiese toepassing. Die meeste outeurs en leksikograwe is inkonsekwent in die identifisering van die woordinisiële segment wat die letter van die alfabet bepaal waaronder die leksikale selfstandige naamwoord geplaas moet word. Gevolglik vind woordeboekgebruikers Zoeloewoordeboeke nie gebruikersuriendelik nie. In hierdie artikel word die beginsel van " $n$ selfstandige naamwoord sonder inisiële klinker" dus voorgestel as 'n metode om nasale naamwoorde in Zoeloe te lemmatiseer. Daar word tot die gevolgtrekking gekom dat dit nie nodig is om op die afleidingsgeskiedenis van 'n leksikale naamwoord in te gaan nie, maar dat daar eerder gefokus moet word op die produk van die werking van die morfofonologiese reëls. Die artikel gee dit ook ter oorweging dat dit nodig is om die onderskeidende kenmerke van die segmente van ' $n$ sillabe te identifiseer en om te erken dat identiese vorme van ' $n$ segment in verskillende segmentele posisies (inisieel, mediaal en finaal) voorkom. Ten slotte word voorgestel dat die prefiks van die nasale 
naamwoord in Zoeloe saamgestel word aan die hand van 'n oop sillabepatroon gedefinieer deur ' $n$ algemene KV-formule gebaseer op 'n VKV-naamwoordprefiks-oopsillabepatroon.

Sleutelwoorde: NAASLIGGENDE LETTER, SAMESTELLING, SAAMGESTEL, KONSONANT, ELEMENT, ETIMOLOGIES, EVOLUSIONER, HOMORGANIES, INISIEEL, INTRA. KLINKER, LEMMA, LEMMATISEER, LEKSIKAAL, MORFOFONOLOGIES, NASAAL, NAAMWOORDKLAS, SEGMENT, SILLABE, KLINKER

\section{Introduction}

Both traditional methods for lemmatising Zulu lexical items, namely the wordstem tradition and the full-word tradition, come in for criticism. These methods lead to controversies among dictionary users, dictionary makers, linguists and metalinguists. Marggraff (1997) agrees with Van Wyk's statement (1995: 82-83) that:

A dictionary is a compilation of lexical items, not a grammar ... All dictionaries therefore assume grammatical knowledge on the part of the user ... In the case of most languages a knowledge of important facts concerning the morphology and even some morphophonological processes are also regarded as a necessary prerequisite to the use of a dictionary.

The application of these two traditional methods in the Zulu dictionary-making process results in dictionaries which:

- are not user-friendly,

- assume grammatical knowledge,

- are linguistically inconsistent, and

- are uneconomical.

The basic function of a dictionary is to provide the dictionary user with comprehensible internal lexicographical information that ought to satisfy the user's needs at that moment. The lemma (head-word), as the most important dictionary entry; commands access into the required internal lexicographical information and indicates "each respective lexical unit in its canonical form" (Zgusta 1971: 249-250). The meaningful rapport between the lemma in Zulu dictionaries and Zulu dictionary users is therefore the primary concern in this analysis of the Zulu nasal noun initial segment:

Most lexicographers derive at least some satisfaction from the knowledge that the product of their labours can help ordinary language users in situations of communicative conflict or deficit (Hartmann 1983: 6).

\subsection{Historical background}

As early as 1857 J.L. Döhne and later álso J.W. Colenso (1861, 1905), A.T. Bryant $(1905,1917)$, C. Roberts (1905) and R.C.A. Samuelson (1923) were already indi- 
vidually confronted with the problem of lemmatising Zulu lexical items. Subsequent recent contributions, including those by Doke et al. (1948, 1958, 1964, 1990), A.C. Nkabinde $(1982,1985)$ and S.L. Nyembezi (1992) among others, do not offer a method different from the two traditional methods for lemmatising Zulu lexical items. The difficulty is however unfairly borne by dictionary makers who were and are expected:

(i) to identify the Zulu lexical word as distinct from the grammatical word;

(ii) to be conversant with the word-initial segment which determines the letter of the alphabet under which Zulu lexical items are recorded;

(iii) to harmonise the Zulu lexicographical rules with linguistic factors;

(iv) to coalesce lexical rules with rules that govern Zulu orthography; and

(v) to choose a method of lemmatising words that seems best for Zulu lexical items (i.e. listing words, as Taylor (1991: 179) says, "in their appropriate phonological form").

\subsection{Textual examples}

In support of the hypothesis that the initial nasal consonant segment of a nounstem is "homorganically pronounced" (Malmkjaer 1991: 26), and therefore needs not be depleted from its composite nasal consonant segment when a nasal noun is lemmatised, this article uses data taken from two Zulu monolingual dictionaries and one bilingual dictionary where more examples can be found:

(i) Monolingual dictionaries

A.C. Nkabinde: Isichazamazwi 2 (1985) (henceforth ACNK)

S.L. Nyembezi: aZ Isichazimazwi Sanamuhla Nangomuso (1992) (henceforth SLNY)

(ii) Bilingual dictionary

C.M. Doke et al.: English - Zulu / Zulu - English Dictionary (1990) (henceforth DMSV)

\subsection{Lemmatising tendency}

The three dominant tendencies adopted by most dictionary makers are:

(i) The Zulu lemmatising practice is based on well-defined lexical theories formulated to suit languages with distinctive writing systems in which the first letter of a noun or a noun-stem is distinct. For example, Table 1 demonstrates that the initial segments in the words pig and kolobe are distinct forms. There can be no arbitrariness in lemmatising or looking up these nouns under the letter of the first consonant segment, viz. P and $K$ respectively. In Zulu the noun ingulube is recorded under the letter $\mathbf{N}$ 
by ACNK, DMSV and SLNY while Döhne (1857) lists it under the letter G. However, ACNK, DMSV and SLNY inconsistently lemmatise most nasal nouns which are classified by form with the noun ingulube either under one letter or under more than one letter. This tendency is evident even with the same author (see examples in Tables 9(a) and 10(a)).

\section{Table 1: Conjunctive and disjunctive writing system}

English: The pig squealed the whole night.

Sotho: Kolobe e tsetsetse bosiu bohle.

Zulu: Ingulube itswininize kwaze kwasa.

(ii) The same lexical item in Zulu is included under or excluded from the letter $\mathbf{N}$ or $\mathbf{M}$ or lemmatised under more than one letter in the case where the phonemic segment of the syllable-initial consonant of the stem, homorganically pronounced, forms the combination in the nasal compound consonant segment or the nasalised consonant segment.

\section{Table 2: Multiletter inclusion or exclusion}

The lemma for imbuthuma is: > -mbuthuma or

\section{$>$-buthuma or}

$>$-bhuthuma.

The lemma for intshakaza is: $\quad>\quad$-ntshakaza or

$>$-tshakaza or

$>$-shakaza.

(iii) The etymological structure of the lexical item at premorphophonological level is used to determine the base-form for the canonical form of the lemma.

Table 3: The etymological lexical structure

PREMORPHOPHONOLOGICAL LEVEL
PHONOLOGICAL PROCESS
LEXICAL ITEM

\begin{tabular}{|c|c|c|c|c|}
\hline $\begin{array}{l}\text {-buthuma } \\
\text {-bhuthuma }\end{array}$ & $\begin{array}{l}N+b \\
N+b h\end{array}$ & $\begin{array}{l}=\mathbf{m b} \\
=\mathbf{m b}\end{array}$ & $>$ & $\begin{array}{l}\text { imbuthuma } \\
\text { imbuthuma }\end{array}$ \\
\hline $\begin{array}{l}\text {-tshakaza } \\
\text {-shakaza }\end{array}$ & $\begin{array}{l}N+t s h \\
N+s h\end{array}$ & $\begin{array}{l}=\mathbf{n t s h} \\
=\mathbf{n t s h}\end{array}$ & $>$ & $\begin{array}{l}\text { intshakaza } \\
\text { intshakaza }\end{array}$ \\
\hline $\begin{array}{l}\text {-hambiso } \\
\text {-linganiso }\end{array}$ & $\begin{array}{l}N+h \\
N+1\end{array}$ & $\begin{array}{l}=\mathbf{n k} \\
=\mathbf{n d}\end{array}$ & $>$ & $\begin{array}{l}\text { inkambiso } \\
\text { indingantiso }\end{array}$ \\
\hline
\end{tabular}




\subsection{Lack of user-friendliness}

These methods of lemmatising Zulu nasal nouns are inconsistent and therefore inconvenient and not user-friendly to dictionary users. The lexemes listed in the speaker's lexicon are those that are regular in his/her current language (Bauer 1988: 195). Thus the words lemmatised in a dictionary should be those that are actually used. Posthumus (1994: 35) discourages the application of etymological forms and says: "It is accepted that language does not operate with non-existing or meaningless forms" (such as those illustrated in Tables 2 and 3, e.g. -buthuma, -bhuthuma, -tshakaza, -shakaza, -hambiso, -linganiso - my examples). To use them as lemmas is therefore "unacceptable". The article postulates that lemmas need to be perceived and treated at a level of "the output of the morphological and phonological rules of the different strata put together" (Malmkjaer 1991: 323, see also Katamba 1989: 257-258). Hence the dictionary user can look up the morphophonological product but not its evolutionary process under the lemma in the dictionary.

\section{A nasal consonant segment}

The protoforms of "all class prefixes are bimorphic in Zulu" except class prefix 1(a) which is "truly monomorphic" (Hlongwane 1995: 62). The evolutionary noun class prefix reduction processes (Mini 1992, 1995) produce noun classes prefixed by "abstract segments" (Katamba 1989: 181, Zgusta 1971: 120) which have perceptible structures of noun class prefixes in some lexical items, for example, - li- in noun class (5), - $\mathrm{ni}$ - in noun classes (9) and (10), and -lu- in noun class (11):

$\begin{array}{lllll}\begin{array}{l}\text { noun class (5) } \\ \text { indiki }\end{array} & \text {-li-: } & & & \\ \text { intshontsho } & \text { ilindiki } & \text { lemma } & > & \text {-ndiki } \\ \text { inkankane } & \text { ilinkankane } & \text { lemma } & > & \text {-ntshontsho } \\ \text { inono } & \text { ilinono } & \text { lemma } & > & \text {-nono } \\ \text { inuku } & \text { ilinuku } & \text { lemma } & > & \text {-nuku } \\ \text { noun class (9) } & \text {-ni-: } & & & \\ \text { imbaba } & \text { inimbaba } & \text { lemma } & > & ? \\ \text { inhlwa } & \text { ininhlwa } & \text { lemma } & > & ? \\ \text { imvula } & \text { inimvula } & \text { lemma } & > & ? \\ \text { intshakaza } & \text { inintshakaza } & \text { lemma } & > & ? \\ \text { ingulube } & \text { iningulube } & \text { lemma } & > & ? \\ \text { noun class (10) } & \text {-ni-: } & & & \\ \text { izinhlwa } & \text { izi-ninhlwa } & \text { lemma } & > & ? \\ \text { izimvula } & \text { izi-nimvula } & \text { lemma } & > & ? \\ \text { izintshakaza } & \text { izi-nintshakaza } & \text { lemma } & > & ? \\ \text { izingulube } & \text { izi-ningulube } & \text { lemma } & > & ?\end{array}$


noun class (11) -lu-:

$\begin{array}{lllll}\text { umbimbi } & u \text {-lumbimbi } & \text { lemma } & > & \text {-mbimbi } \\ \text { undanda } & u \text {-lundanda } & \text { lemma } & > & \text {-ndanda } \\ \text { unyawo } & u \text {-lunyawo } & \text { lemma } & > & \text {-nyawo } \\ \text { unjongwe } & u \text {-lunjongwe } & \text { lemma } & > & \text {-njongwe } \\ \text { umonya } & u \text {-lumonya } & \text { lemma } & > & \text {-monya }\end{array}$

The nasal noun classes (9) and (10) are unique and distinct. They consist of:

- the protoforms of the nasal noun class prefix which have an intravowel nasal consonant element;

- the perceptible protoforms of the nasal noun-class prefix which become homorganic with the initial consonant of the noun-stem; and

- the productive rule that governs incompatibility of adjoined consonant sounds.

The combination of protoforms of the nasal noun-class prefix with the initial consonant of noun-stems under noun classes (9) and (10) creates problems regarding the lemmatising of Zulu nasal nouns. Meinhof (1932: 95-96) states:

When a nasal is preceded by $n<B$. $n i$ the $n$ disappears, e.g.

$n+n y>n y$, e.g. u-nyawo (11) "foot" pl. izinyawo for *izin-nyawo.

$n+n>n$, e.g. izi-ne (10) "four" > *izin-ne.

$n+m>m$, e.g. u-monya (11) "python" pl. izi-monya for *izin-monya, cf.

$i$-mini (9) "middle of the day" pl. izi-mini for *izin-mini.

The nasals remain unchanged before the vowels.

(B. denotes the protoforms of Ur-Bantu, and * denotes protoforms.)

On the basis of a proposition like $i$-mini : izi-mini : *izin-mini, this article attempts to test analogically by a reverse formula that lemmatising practice needs to ignore the morphophonological process in order to pick up initial segments of the noun-stems, that are the morphophonological products. For example, the noun intshakaza, grouped in the same nasal noun class (9) as imini, is selected here to form the problematic part of the equation, that is: If imini : -mini, then intshakaza:?

If

imini (class 9)

$>\underset{i-\operatorname{mini} i}{\mathrm{i}} \quad: \quad i z i-\operatorname{mini}$

*izin-mini (given) and

*in-mini (formula),

then

\begin{tabular}{|c|c|c|c|c|c|}
\hline $\begin{array}{l}\text { intshakaza (class 9) } \\
\text { therefore, the lemma }\end{array}$ & $>$ & $\begin{array}{l}\text { i-ntshakaza } \\
\text { i-ntshakaza } \\
\text { imini } \\
\text { intshakaza }\end{array}$ & $\begin{array}{l}: \\
: \\
>\end{array}$ & $\begin{array}{l}\text { izi-ntshakaza: } \\
\text {-mini and } \\
\text {-ntshakaza. }\end{array}$ & $\begin{array}{l}\text { *izin-ntshakaza and } \\
\text { "in-ntshakaza; }\end{array}$ \\
\hline
\end{tabular}

It is logical to accept that the same theory holds in noun classes (9) and (10) with all nasal nouns whose initial nasal consonant segments are either simple 
or homorganic. For example, the proposed solution to find lemmata for lexical items under noun class (9) listed as examples above is:

$\begin{array}{lll}\text { imbaba } & > & \text {-mbaba } \\ \text { inhlwa } & > & \text {-nhlwa } \\ \text { imoula } & > & \text {-mvula } \\ \text { intshakaza } & > & \text {-ntshakaza } \\ \text { ingulube } & > & \text {-ngulube }\end{array}$

Note that the evolutionary forms of the noun intshakaza, illustrated briefly in Table 14(a) showing developments from Ur-Bantu $-\mathrm{Ni}$-, are too remote to be discussed in detail under lemmatisation. Hence the form *in-ntshakaza is conveniently treated as example to indicate the "protoform" at premorphophonological level.

\subsection{Types of nasal consonant segments}

The two types of nasal consonants that occur in Zulu as consonant segments are:

- the primary nasal consonant segments, and

- the secondary nasal consonant segments.

They can be summarised schematically as in Table 4 where their relations are shown.

\subsubsection{The primary nasal consonant segments}

The primary or radical nasal consonant segment is found in Zulu as:

- a simple alveolar nasal consonant segment $\mathbf{n}$ [n];

- a simple bilabial nasal consonant segment $m[\mathrm{~m}]$;

- a syllabic bilabial nasal consonant segment $m$ [m] which occurs only if it precedes an adjoined consonant, whereas a syllabic alveolar nasal consonant is not permitted in Zulu; and

- an intravowel nasal consonant element, that is, a nasal consonant segment occurring between vowels with no adjoined consonants since a nasal consonant is never preceded by an adjoined consonant in Zulu, unless the preceding adjoined consonant is syllabic.

The features illustrated in Table 5 show no divergence in the system of lemmatisation by the Zulu dictionary makers ACNK, DMSV and SLNY. Under the primary nasal consonant segment type only the syllabic bilabial nasal consonant cluster reflects some problems. The combination of syllabic $\mathbf{m}$ with the initial consonant of the first syllable of the noun-stem creates indistinct forms of initial segments. This is discussed under 2.2 and shown in Tables 6, 7 and 8. 


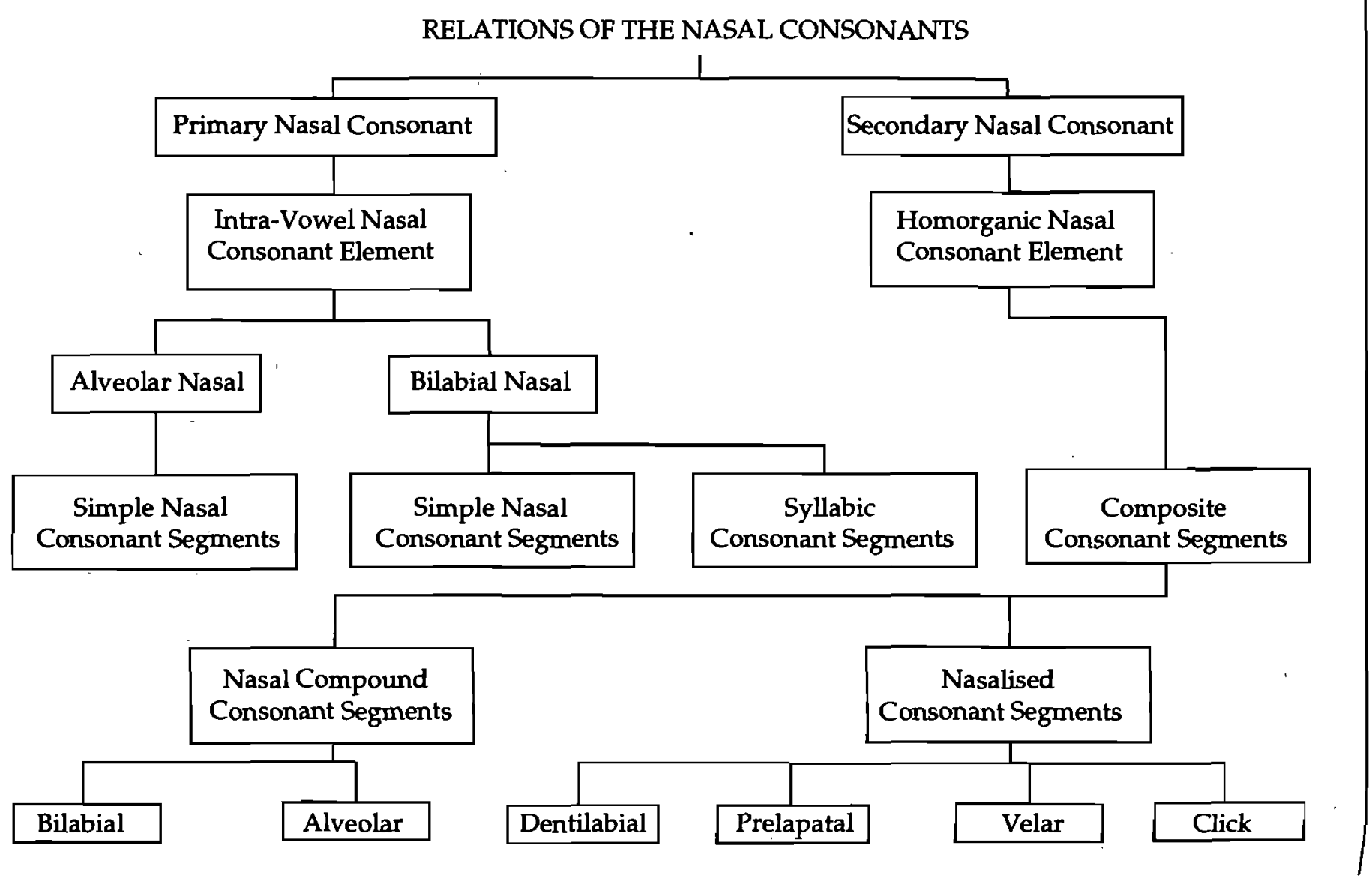




\section{Table 5: The primary nasal consonant segments}

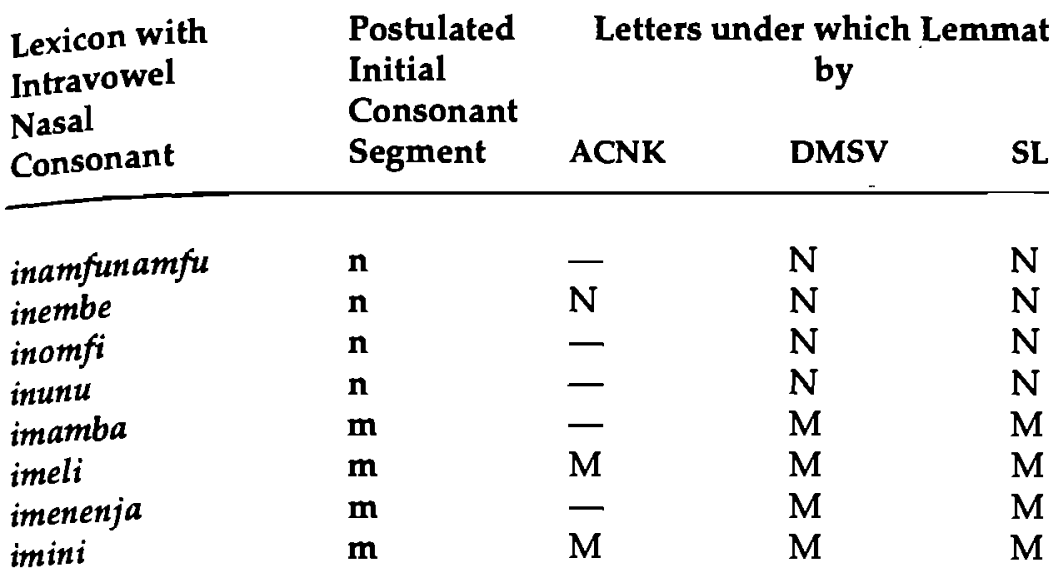

\subsection{Syllabic bilabial nasal consonant vs. homorganic nasal consonant seg- ments}

The ability to distinguish homographic consonant clusters between the syllabic bilabial nasal and the homorganic nasal consonant segments of written lexical items in general Zulu orthography presupposes a knowledge of the Zulu word structure, otherwise lemmatisation becomes problematic. This is attributable to current orthography. Therefore, problems in lemmatisation cannot be solved either with phonetic scripts or with specific diacritic markings for the syllabicity of segments. Hence it becomes difficult to determine or to explain the lexical rule to be applied for the initial consonant segment in both the syllabic bilabial nasal consonant and the homorganic nasal consonant segments occurring at the same segmental environment in a Zulu lexical item.

Doke et al. (1990) acknowledge the existence of this problem. For example, they divide the bilabial consonant into two dictionary alphabets, viz. B (or b) and $\mathbf{6}$, whereby $B$ is an equivalent of $\mathbf{B h}$ (devoiced bilabial explosive) and $\mathbf{6}$ an equivalent of $\mathbf{B}$ (voiced bilabial implosive), that is, $\mathbf{B}=\mathbf{B h}$ and $\mathbf{6}=\mathbf{B}$, but $\mathbf{6} \neq \mathbf{B h}$, hence, $n+B>m b, n+B h>m b$, and $n+6>m b$ (but either $m b h<n+B h$ or $m 6<n+6$ as a single segment is incompatible). They (1990: 15, 57) assert that the two consonants $\mathbf{B}$ (or b) and $\mathbf{6}$ are "phonetically distinct" in Zulu:

Stems of nouns commencing in imb are sometimes recorded under $\boldsymbol{G}$, sometimes under $m b$. When, however, it is ascertainable that the initial of the root is $b$, and in cases where the real initial is to-day unascertainable, these words are recorded under $\boldsymbol{b}$.

The problem is comparatively illustrated in Table 6 by using the "minimal pair test" propounded by Katamba (1989: 22-23). 
Table 6: The minimal pair test

$\begin{array}{llll}\text { Syllabic Nasal } & \text { Lexical } & \text { Homorganic } & \text { Lexical } \\ \text { at Initial } & \text { Item } & \text { Nasal Initial } & \text { Item } \\ \text { Consonant } & & \text { Consonant } & \\ \text { Clusters } & & \text { Segment } & \end{array}$

$\begin{array}{llll}\mathrm{mb} & \text { imbala (class 4) } & \mathrm{mb} & \text { imbala (class 9) } \\ \mathrm{mb} & \text { umbala (class 3) } & \mathrm{mb} & \text { umbalane (class 3a) } \\ \mathrm{mb} & \text { umbethe (class 3) } & \mathrm{mb} & \text { umbekle (class 3a) } \\ \mathrm{mb} & \text { imfula (class 4) } & \mathrm{mf} & \text { imfumba (class 9) } \\ \mathrm{mv} & \text { imvithi (class 4) } & \mathrm{mv} & \text { imvithi (class 9) }\end{array}$

Table 7: The syllabic nasal consonant segments

Lexicon with Postulated Letters under which Lemmatised Syllabic Nasal Initial by $\begin{array}{llll}\text { at Initial Con- } & \begin{array}{l}\text { Consonant } \\ \text { sonant Clusters }\end{array} & \text { Segment }\end{array}$ ACNK $\quad$ DMSV $\quad$ SLNY

\begin{tabular}{lllll}
\hline imbala & B & - & 6 & B \\
umbala & B & B & 6 & B \\
umbethe & B & - & 6 & B \\
imfula & F & - & F & F \\
imvithi & V & - & V & V
\end{tabular}

Table 8: The homorganic nasal consonant segments

\begin{tabular}{|c|c|c|c|c|}
\hline \multirow{2}{*}{$\begin{array}{l}\text { Lexicon with } \\
\text { Initial Homorga- } \\
\text { nic Nasal Con- } \\
\text { sonant Segment }\end{array}$} & \multirow{2}{*}{$\begin{array}{l}\text { Postulated } \\
\text { Initial } \\
\text { Consonant } \\
\text { Segment }\end{array}$} & \multicolumn{3}{|c|}{$\begin{array}{l}\text { Letters under which Lemmatised } \\
\text { by }\end{array}$} \\
\hline & & ACNK & DMSV & SLNY \\
\hline$i m b a$ & m & $\mathrm{Mb}$ & $\mathrm{Mb} / \mathrm{B}$ & $\mathrm{MI}$ \\
\hline umbalane & mb & - & $\mathrm{Mb}$ & $\mathrm{Mb}$ \\
\hline umbekle & $\mathbf{m b}$ & - & B & $\mathrm{Bh}$ \\
\hline imfumba & $\mathrm{mf}$ & - & F & $\mathrm{Mf} / \mathrm{F}$ \\
\hline imoithi & $\mathrm{mv}$ & - & $\mathrm{V}$ & $\mathrm{V}$ \\
\hline
\end{tabular}

\subsection{The secondary nasal consonant segments}

Two secondary nasal types of consonant segments that cause a major problem in lemmatising a Zulu lexical item are: 
- the nasal compound consonant segments, and

- the nasalised consonant segments.

Each type of nasal consonant segment is generated by phonological factors. Each consists of composite consonant clusters with a nasal consonant which is homorganically pronounced. Furthermore, each type of segment constitutes a single (phonetic) sound. The first actual consonant of a noun-stem therefore determines the letter under which the lexical item is recorded (see Tables 9(a) and $(10)(a)$ ). It also distinguishes each lexical item by its form and word meaning (Tables 6 and 12). The fact that the actual nasal consonant is a catalyst for nasal compound consonant segments, makes it distinct from the nasalised type of consonant segments. This feature is only realised by use of phonetic script at postmorphophonological level. The distinction is illustrated in the column "Postulated Initial Homorganic Nasal Consonant" in Tables 9 and 10.

Table 9: The nasal compound consonant segments

PREMORPHOPHONOLOGICAL LEVEL
POSTMORPHOPHONOLOGICAL LEVEL

$\begin{array}{ll}\begin{array}{l}\text { Postulated Initial } \\ \text { Homorganic Nasal } \\ \text { Consonant Segment }\end{array} & \\ & \\ & \\ & \\ \mathbf{m b} & >[\mathrm{mb}] \\ >\mathbf{m b} & >[\mathrm{mb}] \\ >\mathbf{m b} & >[\mathrm{mb}] \\ & >\left[\mathrm{mp}^{\prime}\right] \\ \mathbf{m p} & >\left[\mathrm{mp}^{\prime}\right]\end{array}$

(ii) Alveolar Consonant Segments
$>$ nd

$>$ nd

$>$ nt

$>$ nt

$>\mathrm{ns}$

$>\mathrm{nz}$

$>$ ndl

$>$ nhl
$>$ [nd]

$>$ [nd]

$>$ [nt']

$>$ [nt']

$>$ [nts']

$>$ [ndz]

$>$ [ndf]

$>$ [nt'] 
Table 9(a): The nasal compound consonant segments

Lexicon with

Initial Homor-

ganic Nasal

Consonant

Segments

$\begin{array}{ll}\text { imbaba } & \mathrm{mb} \\ \text { imbiza } & \mathrm{mb} \\ \text { imbuthuma } & \mathrm{mb} \\ \text { impandla } & \mathrm{mp} \\ \text { impoko } & \mathrm{mp} \\ \text { impontshi } & \mathrm{mp} \\ \text { indaxandaxa } & \mathrm{nd} \\ \text { indikimba } & \mathrm{nd} \\ \text { indinganiso } & \mathrm{nd} \\ \text { indodakazi } & \mathrm{nd} \\ \text { intezazane } & \mathrm{nt} \\ \text { intombi } & \mathrm{nt} \\ \text { insada } & \mathrm{ns} \\ \text { insephe } & \mathrm{ns} \\ \text { insumpa } & \mathrm{ns} \\ \text { inhliziyo } & \mathrm{nhl} \\ \text { inhlwa } & \mathrm{nhlw}\end{array}$

Postulated Initial Homorganic Nasal

Consonant

Segments

nhlw
Letters under which Lemmatised

by

ACNK DMSV SLNY

$\mathrm{Mb} /-/ \mathrm{Bh} \quad \mathrm{Mb} / \mathrm{B} / \mathrm{Bh} \quad \mathrm{Mb} / \mathrm{B} / \mathrm{Bh}$

$\mathrm{Mb} /-/ \mathrm{Bh} \quad-/-/ \mathrm{Bh} \quad \mathrm{Mb} /-/ \mathrm{Bh}$

$-/-1-\quad-/-/ \mathrm{Bh} \quad \mathrm{Mb} / \mathrm{B} / \mathrm{Bh}$

$-/-/ \mathrm{Ph} \quad-/-/ \mathrm{Ph} \quad \mathrm{Mp} /-/ \mathrm{Ph}$

$-/ \mathrm{P} /-\quad-/ \mathrm{P} /-\quad \mathrm{Mp} /-/-$

$-/-/ \mathrm{Ph} \quad \mathrm{Mp} /-/-\quad \mathrm{Mp} / \mathrm{P} / \mathrm{Ph}$

$-/ \mathrm{D} /-\quad \mathrm{Nd} / \mathrm{D} /-\quad \mathrm{Nd} / \mathrm{D} /-$

$-/ D /-\quad-/ D /-\quad \mathrm{Nd} / \mathrm{D} /-$

$-/-/-\quad \mathrm{Nd} /-/ \mathrm{L} \quad \mathrm{Nd} /-/-$

$-/ \mathrm{D} /-\quad-/ \mathrm{D} /-\quad-/ \mathrm{D} /-$

$-/-/ \mathrm{Th} \quad \mathrm{Nt} /-/-\quad \mathrm{Nt} /-/ \mathrm{Th}$

$-/-/-\quad-/-/ \mathrm{Th} \quad \mathrm{Nt} /-/ \mathrm{Th}$

$-/ \mathrm{S} /-\quad$ Ns/-/- Ns/S/-

Ns/-1- Ns/S/- Ns/S/-

$-/ S /-\quad-/ S /-\quad$ Ns/S/-

$-/-1-\quad-/ \mathrm{Hl} /-\quad \mathrm{Nhl} /-/-$

$-/ \mathrm{Hl} /-\quad$ Nhlw/Hl/- $-/ \mathrm{Hl} /-$

Table 10: The nasalised consonant segments

\section{PREMORPHOPHONOLOGICAL \\ LEVEL \\ POSTMORPHOPHONOLOGICAL LEVEL}

(i) Dentilabial Consonant Segments

Postulated Initial

Homorganic Nasal

Consonant Segment

Phonetic Sounds

$$
\begin{aligned}
& N+f \\
& N+v
\end{aligned}
$$

$>\mathbf{m f}$

$>[\mathrm{m} \phi \mathrm{f}]$

$>\mathbf{m v}$

$$
>\text { [mфv] }
$$

(ii) Prepalatal Consonant Segments

$$
\begin{aligned}
& N+y \\
& N+j \\
& N+s h \\
& N+t s h
\end{aligned}
$$

$>$ [n]

$>$ [nd3]

$>$ [nt $\left.]^{\prime}\right]$

$>$ [nt ['] 
(iii) Velar Consonant Segments

$N+g$
$N+k$
$N+k h$
$N+h$
$N+k l$

$\begin{array}{ll}>\mathbf{n g} & >[\mathrm{ng}] \\ >\mathbf{n k} & >\left[\mathrm{nk}^{\prime}\right] \\ >\mathbf{n k} & >\left[\mathrm{nk}^{\prime}\right] \\ >\mathbf{n k} & >\left[\mathrm{k}^{\prime}\right] \\ >\mathbf{n k l} & >\left[\mathrm{nk}^{\prime}\right]\end{array}$

(iv) Clicks Consonant Segments

$\begin{array}{lll}\mathrm{N}+\mathrm{ch} & >\mathbf{n c} & >[\mathrm{g} /] \\ \mathrm{N}+\mathrm{c} & >\mathbf{n g c} & >[\mathrm{g} / \mathrm{g}] \\ \mathrm{N}+\mathrm{gc} & >\mathbf{n g c} & >[\mathrm{g} / \mathrm{g}] \\ \mathrm{N}+\mathrm{qh} & >\mathbf{n q} & >[\mathrm{n} !] \\ \mathrm{N}+\mathrm{q} & >\mathbf{n g q} & >[\mathrm{n} ! \mathrm{g}] \\ \mathrm{N}+\mathrm{gq} & >\mathbf{n g q} & >[\mathrm{g} ! \mathrm{g}] \\ \mathrm{N}+\mathrm{xh} & >\mathbf{n x} & >[\mathrm{n} / \mathrm{I} \\ \mathrm{N}+\mathrm{x} & >\mathbf{n g x} & >\mathrm{n} / \mathrm{g}] \\ \mathrm{N}+\mathrm{gx} & >\mathbf{n g x} & >[\mathrm{g} / \mathrm{g}]\end{array}$

Table 10(a): The nasalised consonant segments

\begin{tabular}{|c|c|c|c|c|}
\hline $\begin{array}{l}\text { Lexicon with } \\
\text { Initial Homor- } \\
\text { ganic Nasal } \\
\text { Consonant } \\
\text { Segment }\end{array}$ & $\begin{array}{l}\text { Postulated } \\
\text { Initial Hom- } \\
\text { organic Nasal } \\
\text { Consonant } \\
\text { Segment }\end{array}$ & Letters u & $\begin{array}{l}\text { which Lemm } \\
\text { by }\end{array}$ & atised \\
\hline imfe & mf & $-/ F /-$ & $-/ F /-$ & $\mathrm{Mf} / \mathrm{F} /-$ \\
\hline imfene & mf & $-/ F /-$ & $-/ F /-$ & $\mathrm{Mf} / \mathrm{F} /-$ \\
\hline imvakazi & mv & $-/ \mathrm{V} /-$ & $-/ \mathrm{V} /-$ & $\mathrm{Mv} / \mathrm{V} /-$ \\
\hline imoula & $\mathbf{m v}$ & $-1-1-$ & $\mathrm{Mv} / \mathrm{V} /-$ & $\mathrm{Mv} / \mathrm{V} /-$ \\
\hline inyama & ny & $-1-1-$ & $\mathrm{Ny} /-/-$ & $\mathrm{Ny} /-/-$ \\
\hline inyanga & ny & Ny/-/- & Ny/Vowel A & $\mathrm{Ny} /-/-$ \\
\hline inyoka & ny & Ny/-/- & Ny/Vowel O & $\mathrm{Ny} /$ Vowel $\mathrm{O}$ \\
\hline inja & $\mathbf{n j}$ & $\mathrm{Nj} /-/-$ & $\mathrm{Nj} / \mathrm{J} /-$ & $\mathrm{Nj} /-/-$ \\
\hline injobo & nj & $-1-$ & $-/ J /-$ & $-/ J /-$ \\
\hline intsha & ntsh & $-/-/$ Sh & $-/-/ \mathrm{Sh}$ & $-/-/ \mathrm{Sh}$ \\
\hline intshakaza & ntsh & $-/-/$ Sh & Ntsh/Tsh/- & Ntsh/Tsh/Sh \\
\hline ingaco & ng & $-/ G /-$ & $\mathrm{Ng} /-/-$ & $\mathrm{Ng} / \mathrm{G} /-$ \\
\hline ingobo & ng & $\mathrm{Ng} /-/-$ & $\mathrm{Ng} / \mathrm{G} /-$ & $\mathrm{Ng} / \mathrm{G} /-$ \\
\hline inkambiso & nk & $-/-/ \mathrm{H}$ & $\mathrm{Nk} /-/ \mathrm{H}$ & $\mathrm{Nk} /-/ \mathrm{H}$ \\
\hline inkantolo & $\mathbf{n}$ & $-1-1-$ & $\mathrm{N} x /-/ \mathrm{Xh}$ & $\mathrm{Nx} /-/-$ \\
\hline
\end{tabular}




\section{Analysis}

The dictionary entry consists of two parts (Zgusta 1971: 249-252). The first part is called the lemma (head-word), which indicates the lexical item itself. This part is most important since it acts as a lexicographic information cursor by which the dictionary entry is identified. The second part contains all information that refers to the first part. Access to the second part is never direct. It is always reached through the first part.

Bauer (1988: 9) comments on how words differ and states that:

- the grammatical word is discussed in terms of its description, and comprises the second part of the dictionary entry, e.g. verb, noun, past participle, etc., while

- the dictionary word is discussed in terms of its form (orthography or spelling) and comprises the first part of the dictionary entry, i.e. the lemma (head-word).

This article therefore analyses the first part of the dictionary entry.

\subsection{The syllable and the segment}

The syllable is a unit intermediate between the segment and the word. The Zulu lexical item is constructed on an open syllable pattern. For the facilitation of the lexicographic principle of lemmatisation, each syllable structure is perceived in this article to consist of a consonant segment $C$ plus a vowel segment $V$, based on a CV-formula. According to Abercrombie (1980: 39, 42), a vowel is a segment of a syllable which can stand alone as a syllable to form a lone-vowel syllable, while a consonant is a segment of a syllable which, when placed alone as a syllable, becomes subjected to laws that regulate syllabic consonants and sounds collocation. This article examines the form and function of a nasal noun initial segment by which the lemma is identified in a Zulu dictionary. Abercrombie (1980: 39) asserts that "the segments of the syllable are identified by their sound".

\subsubsection{Form and function}

The algorithm is conveniently derived from Clements and Keyser (1983). It is applied with the purpose to define the form (Tables 11(a) and 11(b)) and function (Table 12) of a Zulu syllable. It forms the basis for arguments and examples throughout this article. It maintains that:

(i) fully formed core syllables must satisfy the language-particular syllable structure conditions;

(ii) fully formed core syllables are constructed in a pattern so that:

- V-elements are prelinked to core syllables and C-elements to the left are adjoined one by one as long as the configuration resulting at each step satisfies all relevant syllable structure conditions; 
- the syllable-initial consonants are maximised to the extent consistent with the syllable structure conditions of the language in question; and

- the construction of a syllable is in onion-like fashion, that is, built up from the centre outward (Clements and Keyser 1983: 38), hence the rule that applies to the identification of a segment can be likened to "the onion metaphor" (Katamba 1989: 258-259).

Similarly, the segment in a lexical item from the Zulu lexicon is structured in the same fashion as characterised above. The difference lies in the autonomy of the phonetic value of each segment. Each segment, either the vowel segment or the consonant segment, constitutes its own sound by which it is identifiable. The form of a syllable pattern in a lexical nasal noun can be featured as follows:

Table 11(a) intshakaza $=\mathrm{V}+\mathrm{CV}+\mathrm{CV}+\mathrm{CV}$

Table 11(b) intsha $=\mathrm{V}+\mathrm{CV}$

The first V-element represents a lone-vowel syllable and/or a vowel segment. It functions as a word-category marker (see Tables 11(a), 11(b), 14(a) and 14(b)). Hence, it influences change in lexical form and contributes to change in a word meaning. The noun in Table $11(a)$ is constructed of four syllables or of seven segments $(4 \mathrm{~V}+3 \mathrm{C})$ and in Table $11(\mathrm{~b})$ of two syllables or three segments $(2 \mathrm{~V}+$ C). While proposals in this article are to:

- lemmatise a nasal noun without its initial vowel, and

- recognise the first homorganic nasal consonant in a nasal composite consonant segment of a noun-stem for lemmatisation,

the structure of a lemma can therefore for example be constructed as follows:

Table 11(a), the lemma for intshakaza > -ntshakaza $(\mathrm{CV}+\mathrm{CV}+\mathrm{CV})$, and

Table 11(b), the lemma for intsha > -ntsha (CV).

Table 11(a): Form of a syllable and a segment

LEXICAL ITEM

MORPHOPHONOLOGICAL

PROCESS

SYLLABLES

SEGMENTS

SOUNDS

PATTERN

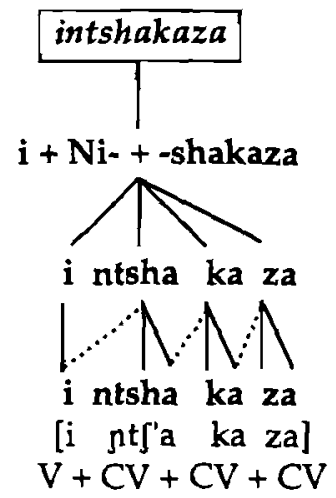


Table 11(b): Form of a syllable and a segment

LEXICAL ITEM

MORPHOPHONOLOGICAL PROCESS

SYLLABLES

SEGMENTS

SOUNDS

PATTERN

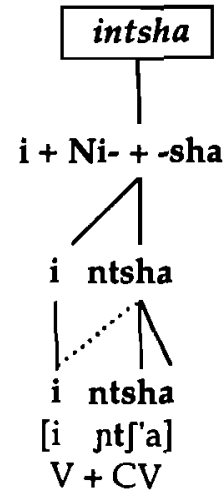

DMSV records the word intsha with lemma -sha under the letter S. It lists the word intshakaza under the letter $\mathbf{N}$ with lemma -ntshakaza. ACNK and SLNY lemmatise both words intsha and intshakaza under the letter $\mathbf{S}$ with lemmas sha and -shakaza respectively. SLNY lemmatises the word intshakaza under three different letters: $\mathbf{N}$ (-ntshakaza), $\mathbf{T}$ (-tshakaza) and $\mathbf{S}$ (-shakaza). This inconsistency is well illustrated in Table 10 (a). It is paradoxical that DMSV lists the segment $\mathbf{n t s h}$ separately as a dictionary entry under the letter $\mathbf{N}$ whereas it records the word intsha and many more with the same form in the initial position of the nasal noun-stem, under the letters $\mathbf{S}$ or T. However, Doke et al. (1996: 606) justify their inconsistency by saying:

ntsh [nt5'] Prepalatal nasal preceding the ejective prepalatal affricate, generally the result of homorganic nasal influence upon $s h$, but sometimes upon tsh. (For words commencing in intsh-or izintsh-not listed under $-n t s h$ see under $-s h$ or $-t s h$.

\subsection{Internal cohesion of a segment}

The initial nasal consonant segment in various Zulu word categories is also identifiable by form and function. It is observed in the following examples that the morphophonological product in each word category overrides the morphophonological process.

\subsubsection{Syntactic application}

The sentences in Table 12 illustrate a comment by Nkabinde (1992: 85) that:

The structure and function of words are closely interrelated. This makes it difficult to treat the morphology of words apart from their syntactic application. 
It can be observed that the segment ntsh of the core syllable-initial consonant maintained its form as well as its function in each word category as illustrated in Tables 11(a), 11(b) and 12 .

\section{Table 12: Syntactic application}

(i) Intshakaza isiqalile ukushazwa. (Noun):

The flower-tuft has begun to wither.

(ii) Le ntshakaza imhlophe qwa. (Demonstrative):

This flower-tuft is snow-white.

(iii) Yiphunga lentshakaza leli olichazayo. (Possessive):

It is the flower-tuft's smell that you are describing.

(iv) Lo mmbila awunantshakaza. (Negative):

This maize stalk has no flower-tuft.

(v) Lo mmbila usunentshakaza. (Affirmative):

This maize plant has now grown a flower-tuft.

(vi) Yintshakaza lena obuza ngayo. (Copulative):

It is the flower-tuft that you are inquiring about.

(vii) Izilokazane ziqaqele entshakazweni. (Locative):

Insects adhere in a thick mass around the flower-tuft.

(viii) Unezinwele ezimayikayika njengentshakaza. (Adverb):

You have hair hanging and flapping about like a flower-tuft.

(ix) Sengibasathe ntshakaza uyamila, lutho. (Vocative):

I have waited for a long time for (you) the flower-tuft to grow, but there is no progress.

\subsubsection{Positional mobility of a composite segment}

The same nasal consonant composite segment can occupy different positions in a lexical item from the Zulu lexicon without losing its form and phonetic value. It can be placed in the initial syllable, medial syllable or final syllable positions in lexical items. The common practice of depleting a lemma's actual initial nasal consonant from its combination with the nasal consonant composite segment in its initial position in the first syllable of the noun-stem is discouraged in this article. This is demonstrated in Table 13.

\section{Table 13: Positional mobility of a composite segment}

$\begin{array}{lll}\text { Initial syllable: ntsh } & > & \text { [nt ['] } \\ \text { e.g. intshakaza; intsha; intshibongo } & & \\ \text { Medial syllable: ntsh } & > & \text { [nt '] } \\ \text { e.g. ipentshisi; isankuntshane } & \end{array}$


Final syllable:

ntsh

[nt5']

e.g. iwolintshi; inkwantshu; impontshi

\subsubsection{Reduplication}

In the ordinary writing system, the first and second parts of reduplicated stems in a lexical item are joined to form a single lexical item which is written according to the current Zulu morphophonological form. But, when some dictionary makers lemmatise, they still change the first part of such a lexical item to reflect its form at premorphophonological level. This can be illustrated by comparing ACNK DMSV and SLNY in Table 13(a). It can be observed that this does not greatly affect the lexical items which are categorised under primary nasal consonant segments. DMSV and SLNY demonstrate a uniform approach under this category e.g. inamfunamfu. Dictionary makers tend to differ when lemmatising the lexical items with duplicated stems under the secondary nasal composite consonant segments, e.g. inkelenkele. The postulated initial homorganic nasal composite segment for the noun inkelenkele is nk. For instance:

- ACNK records this noun under the letter $\mathrm{K}$ as -KHELENKELE and under $\mathrm{H}$ as -HELE(N)HELE;

- DMSV records it under the letter $\mathrm{H}$ as -hele(n)kele and under $\mathrm{N}$ as -nkelenkele; and

- SLNY lists it under the letter $\mathrm{H}$ as -hele(n)hele and under $\mathrm{N}$ as -nkelenkele.

In Table 13(a), the initial segments which contrast with the postulated initial segment in each lexical item, are highlighted under each author.

\section{Table 13(a): Reduplicated noun-stems}

\begin{tabular}{|c|c|c|c|c|}
\hline $\begin{array}{l}\text { Lexicon with } \\
\text { Homorganic } \\
\text { Nasal Initial } \\
\text { Consonant } \\
\text { Element }\end{array}$ & $\begin{array}{l}\text { Postulated } \\
\text { Homorganic } \\
\text { Nasal } \\
\text { Consonant } \\
\text { Segment }\end{array}$ & Letters un & $\begin{array}{l}\text { which Lemn } \\
\text { by }\end{array}$ & atised \\
\hline $\begin{array}{l}\text { inamfunamfu } \\
\text { imbidlimbidli } \\
\text { impithimpithi } \\
\text { indaxandaxa } \\
\text { inzuthunzuthu } \\
\text { intshiphantshipha } \\
\text { inkavunkavu } \\
\text { inkelenkele } \\
\text { inkinyankinya } \\
\text { inkumunkumu } \\
\text { inxakanxaka }\end{array}$ & $\begin{array}{l}- \\
\text { mb } \\
\text { mp } \\
\text { nd } \\
\text { nz } \\
\text { ntsh } \\
\text { nk } \\
\text { nk } \\
\text { nk } \\
\text { nk } \\
\text { nx }\end{array}$ & $\begin{array}{l}- \\
-/-/- \\
-/-/ \mathbf{P h} \\
-/ \mathrm{D} /- \\
-/-/- \\
-/-/- \\
-/-/ \mathbf{K h} \\
-/ \mathbf{K h} / \mathbf{H} \\
-/-/ \mathbf{K h} \\
-/-/ \mathbf{K h} \\
-/-/-\end{array}$ & $\begin{array}{l}\mathrm{N} \\
-/-/ \mathrm{Bh} \\
-/-/ \mathrm{Ph} \\
\mathrm{Nd} / \mathrm{D} \\
\mathrm{Nz} / \mathrm{Z} \\
\mathrm{Ntsh} /-/ \mathrm{Sh} \\
\mathrm{Nk} /-/- \\
\mathrm{Nk} /-/ \mathrm{H} \\
\mathrm{Nk} /-/- \\
\mathrm{Nk} /-/ \mathrm{Kh} \\
-/ \mathrm{X} /-\end{array}$ & $\begin{array}{l}\mathrm{N} \\
\mathrm{Mb} /-/ \mathrm{Bh} \\
-/-/- \\
\mathrm{Nd} / \mathrm{D} /- \\
\mathrm{Nz} / \mathrm{Z} /- \\
\mathrm{Ntsh} /-/ \mathrm{Sh} \\
\mathrm{Nk} /-/ \mathrm{Kh} \\
\mathrm{Nk} /-/ \mathrm{H} \\
\mathrm{Nk} /-/ \mathrm{Kh} \\
\mathrm{Nk} /-/ \mathrm{Kh} \\
\mathrm{Nx} / \mathrm{X} /-\end{array}$ \\
\hline
\end{tabular}


Internal stability of a segment

The ordering of consonant items within the same nasal consonant composite segment of a syllable is fixed and noncontrastive. Hence it is not feasible to rearrange the same items and still arrive at the same or at the canonical nasal consonant composite segment. The constraint is ascribed to the rules of generative linguistics and incompatible sound laws which determine the acceptability of the morphophonological product, e.g.

(i) $\mathrm{N}(\mathrm{tsh}, \mathrm{sh})=>$ ntsh, but

(ii) $\quad \mathrm{N}(\mathrm{t}, \mathrm{ts}$, th, ths, st, sth, ht, hs, hts) $\neq>$ ntsh.

Taylor (1991: 130-131), writing about the possibility of combining words into phrases, says that it is "a question of the compatibility of the feature specifications of the component forms, compatibility being in terms of selection restrictions". The acceptability of word combinations is clear: "either the feature specifications are compatible, or they are not". The same applies to the possibility of combining letters into segments, and the acceptability of these segments, in this case consonant combinations. The combination in example (ii) above does not satisfy the conditions of Zulu segment structures. The pattern of consonant configuration that results after operation in each step obeys neither the distributive law nor satisfies laws regulating the compatibility of sounds in Zulu. Therefore the operation in example (ii) cannot be acceptable in Zulu.

\subsubsection{Evolutionary morphophonological product}

The development of language orthography usually responds to current language demands. Logically, the current orthography of a lexical item normally indicates the first letter in the initial segment of the first syllable of the nounstem under which the lexical item is listed in Zulu. Most dictionary-makers indicate this by a capital letter and precede it by a hyphen. When Theunissen (1943: 83) illustrates the use of capitals for the initial letter of the stem of words, he says:

It should be noted that some Class : 5 (Doke) nouns with Class : 3 (Doke) plurals, have a different stem in the singular than in the plural, e.g. iNkosi but amaKhosi, iNdodakazi but amaDodakazi.

The nouns iNkosi, iNdodakazi and iNtshakaza belong to the same noun class. This article asserts that they are, in principle, recorded under the same letter, i.e. N. In practice, however, this is not so. ACNK, DMSV and SLNY lemmatise these nouns differently. They seem to have considered the evolutionary morphophonological process more important than the lexical product itself. To prove that a lexicographical consistency exists instead of this practised inconsistency, this article provides a column for postulated initial consonant segments 
in Tables 9(a), 10(a) and 13(a) that shows uniformity in the homorganic nasal composite consonant segments, viz. nk, nd and ntsh respectively, for these nouns.

Table 14: Evolutionary morphophonological product

(a)

EVOLUTIONARY

CURRENT FORM

CONTEXTUAL FORM

INITIAL SEGMENT

SOUND

(b)

EVOLUTIONARY

CURRENT FORM

CONTEXTUAL FORM

INITIAL SEGMENT SOUND
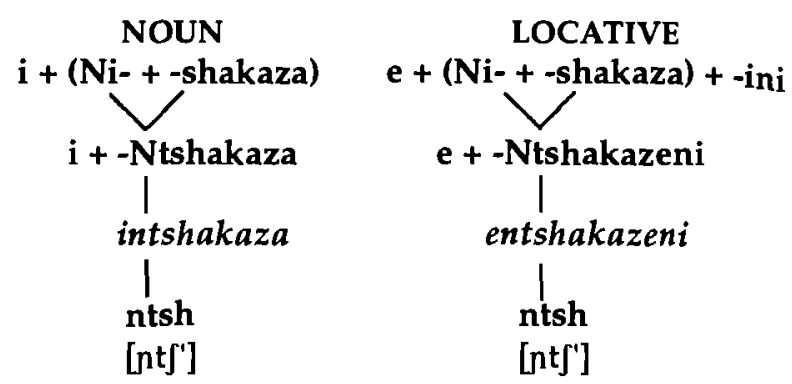

NOUN

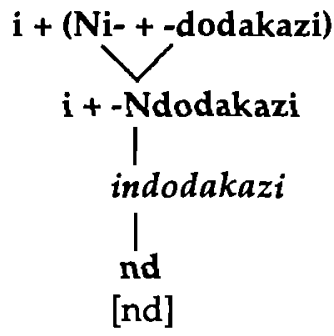

LOCATIVE

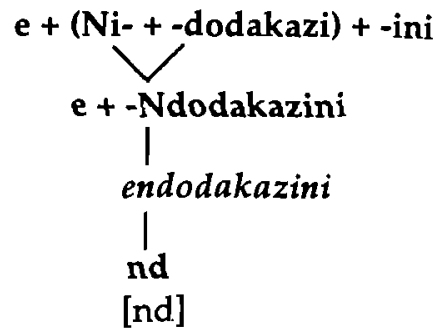

\section{Conclusion}

It is difficult to engage in lemmatising in Zulu without adopting the word-stem tradition. The method for selecting the letter under which the lexical item, the nasal noun in particular, is to be recorded or looked up in the dictionary, remains controversial. Hence inconsistency, uncertainty, lack of user-friendliness, linguistic assumptions and uneconomical methods of compiling are all unavoidable. This article therefore proposes that the nasal consonant at the initial segment of the nasal noun-stem not be depleted from its homorganic composite nasal consonant segment when a nasal noun is lemmatised. All lexical items used as examples are listed in existing dictionaries, with some showing segments that are contrary to the segments shown in the column for the postulated initial homorganic nasal consonants. 
Glossary of Zulu words in the text

\begin{tabular}{|c|c|}
\hline amadodakazi & daughters \\
\hline amakhosi & chiefs \\
\hline imamba & mamba (Dendroaspis spp.) \\
\hline imbaba & the palm of the hand \\
\hline imbala (class 4) & colours \\
\hline imbala (class 9) & actuality, reality; fire spot on the leg \\
\hline imbidlimbidli & heavy, stout person \\
\hline imbiza & earthenware pot \\
\hline imbuthuma & fire of glowing embers; large log fire \\
\hline imeli & mare \\
\hline imenenja & manager \\
\hline imfe & sweet reed \\
\hline imfene & baboon \\
\hline imfula & rivers \\
\hline imfumba & pile of goods \\
\hline imini & middle of the day \\
\hline impandla & baldness; bald-headed person \\
\hline $\begin{array}{l}\text { impithimpithi } \\
\text { impoko }\end{array}$ & $\begin{array}{l}\text { confusion, commotion; confused affair } \\
\text { grass flower }\end{array}$ \\
\hline impontshi & pouch; small skin bag \\
\hline imvakazi & $\begin{array}{l}\text { veil; hair-fringe hanging over the forehead (of a young } \\
\text { woman) }\end{array}$ \\
\hline imvithi (class 4) & species of large, shady tree \\
\hline imvithi (class 9) & wreckage; heap of ruins \\
\hline imvula & rain \\
\hline inamfunamfu & sticky substance \\
\hline indaxandaxa & person or thing dripping wet; lazy person; coward \\
\hline indiki & person suffering from an hysterical disease \\
\hline indikimba & subject; main facts, essential points \\
\hline indinganiso & measure, standard for guidance \\
\hline indodakazi & daughter \\
\hline inembe & $\begin{array}{l}\text { the last matter passed at confinement; medicine used } \\
\text { to aid parturition }\end{array}$ \\
\hline ingaco & cultivated field \\
\hline ingobo & small stomach of a beast \\
\hline ingulube & pig \\
\hline inhliziyo & heart \\
\hline inhlwa & flying termite \\
\hline inja & $\operatorname{dog}$ \\
\hline injobo & $\begin{array}{l}\text { a strip of wild-cat's skin forming the loin-covering of } \\
\text { a man }\end{array}$ \\
\hline inkambiso & custom \\
\hline inkankane & hadeda ibis (Bostrychia hagedash) \\
\hline inkantolo & magistrate's court; charge office \\
\hline inkavunkavu & course, husky kind of food \\
\hline
\end{tabular}




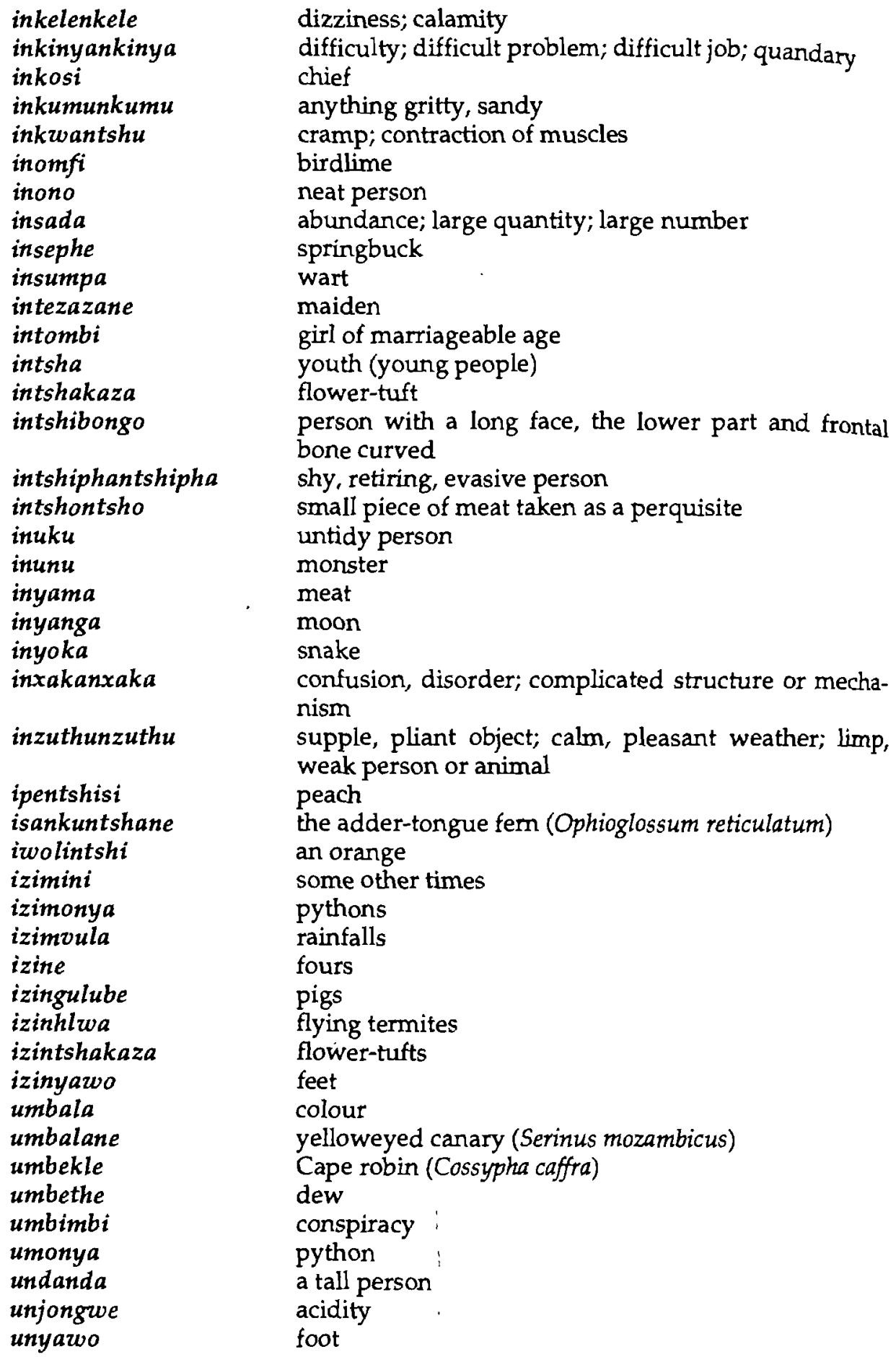

dizziness; calamity

difficulty; difficult problem; difficult job; quandary chief

anything gritty, sandy

cramp; contraction of muscles

birdlime

neat person

abundance; large quantity; large number

springbuck

wart

maiden

girl of marriageable age

youth (young people)

flower-tuft

person with a long face, the lower part and frontal bone curved

shy, retiring, evasive person

small piece of meat taken as a perquisite

untidy person

monster

meat

moon

snake

confusion, disorder; complicated structure or mechanism

supple, pliant object; calm, pleasant weather; limp, weak person or animal

peach

the adder-tongue fern (Ophioglossum reticulatum)

an orange

some other times

pythons

rainfalls

fours

pigs

flying termites

flower-tufts

feet

colour

yelloweyed canary (Serinus mozambicus)

Cape robin (Cossypha caffra)

dew

conspiracy

python

a tall person

acidity

foot 


\section{Bibliography}

Abercrombie, D. 1980. Elements of General Phonetics. Edinburgh: University Press. Bauer, L. 1988. Introducing Linguistic Morphology. Edinburgh: University Press.

Clements, G.N. and S.J. Keyser. 1983. CV Phonology: A Generative Theory of the Syllable. Cambridge: The MIT Press.

Döhne, J.L. 1857. Zulu-Kafir Dictionary. Cape Town.

Doke, C.M., D.M. Malcolm, J.M.A. Sikakana and B.W. Vilakazi. 1990. English-Zulu/Zulu-English Dictionary. Johannesburg: Witwatersrand University Press.

Hartmann, R.R.K. 1983. Lexicography: Principles and Practice. London: Academic Press.

Hlongwane, J.B. 1995. Growth of the Zulu Language and its Structural Changes. South African Joumal of African Languages 15(2): 60-65.

Katamba, F. 1989. An Introduction to Phonology. London: Longman.

Lyons, J. 1971. Introduction to Theoretical Linguistics. Cambridge: University Press.

Malmkjaer, K. 1991. The Linguistics Encyclopedia. London: Routledge.

Marggraff, M. 1997. Aspects of Lemmatization in Nguni. Unpublished paper presented at the Second International Conference of the African Association for Lexicography, held at the University of Natal, Durban, 14-16 July 1997.

Meinhof, C. 1932. Introduction to the Phonology of the Bantu Languages. Berlin: Dietrich Reimer.

Mini, B.M. 1992. Problems in Lexicographical Work in the Xhosa Dictionary Project. General and Technical Lexicography in Practice. Pretoria: National Terminology Services.

Mini, B.M. 1995. Lexicographical Problems in isiXhosa. Lexikos 5: 40-56.

Mzolo, D. 1968. The Zulu Noun without the Initial Vowel. African Studies 27(4): 195-210.

Nkabinde, A.C. 1975. A Revision of the Word Categories in Zulu. Unpublished D.Litt et Phil. dissertation. Pretoria: University of South Africa.

Nkabinde, A.C. 1985. Isichazamazwi 2. Cape Town: Oxford University Press.

Nkabinde, A.C. 1992. Lexicography in Zulu. General and Technical Lexicography in Practice. Pretoria: National Terminology Services.

Nyembezi, S.L. 1992. aZ Isichazimazwi Sanamuhla Nangomuso. Pietermaritzburg: Reach Out.

Posthumus, L.C. 1994: Word-based versus Root-based Morphology. South African Journal of African Languages 14(1): 28-36.

Taylor, J.R. 1991. Linguistic Categorization: Prototypes in Linguistic Theory. Oxford: Clarendon Press. Theunissen, S.B. 1943. Zulu Orthography. Native Teachers' Journal 23: 81-83.

Van Wyk, E.B. 1995. Linguistic Assumptions and Lexicographical Traditions in the African Languages. Lexikos 5: 82-96.

Zgusta, L. 1971. Menual of Lexicography. Prague: Academia/The Hague: Mouton.

Ziervogel, D. 1986. Speech Sounds and Sound Changes of the Bantu Languages of South Africa. Pretoria: Unisa. 